\title{
Four aeroterrestrial algae grown at a special substrate of deglaciated coastal areas of Petuniabukta, Svalbard
}

\author{
Lenka Raabová ${ }^{*}$ Lubomír Kováčik \\ Comenius University in Bratislava, Department of Botany, Faculty of Natural Sciences, \\ Revova 39, SK-811 02 Bratislava, Slovakia
}

\begin{abstract}
The bone remnants of sea mammals are frequently dispersed everywhere in coastal areas of Svalbard Archipelago represent a specific natural habitat which is colonized by aeroterrestrial microscopic algae. Such bone habitat might be considered an analogue to stone substrates. However, bone habitats are not included in ecological studies of polar region. In the present study, thorough observations were made on some algal strains isolated to laboratory cultures. They included two green algal species Pseudodictyochloris multinucleata and Tetracystis pulchra, as well as two stramenopile algal species Heterococcus papillosus and Xanthonema debile. All these taxa are new additions to the Svalbard flora.
\end{abstract}

Key words: algae, mammalian bone remnants, Arctic

DOI: $10.5817 / \mathrm{CPR} 2013-2-16$

\section{Introduction}

Algae as much of cyanobacteria occur in practically all Earth's environments and some species are capable of growing in wide ranges of natural conditions. For terrestrial habitats of both Arctic and Antarctic, extremities of environmental stress occur, principally freezing and desiccation. Furthermore, the persistent cold temperature is often accompanied by freeze-thaw cycles, extreme fluctuations in irradiance (including ultraviolet radiations) and large variations in nutrient supply and salinity.
Nonetheless, polar regions are inhabited by numerous pro- and eukaryotic oxyphototrophic microorganisms, which are indispensable e.g. in soil formation process and preparing substrates for subsequent colonizers. The cyanobacteria and algae are also known as the prominent primary colonizers after deglaciation and therefore play an important role as producers of early detectable biomass on newly created habitats. (Elster et Benson 2004, Thomas al. 2008, Kim et al. 2008).

Received October 18, 2013, accepted November 20, 2013.

*Corresponding author: Lenka Raabová <lenka.raabova@gmail.com>

Acknowledgements: This study was supported by the grants Nos. UK/181/2013 and VEGA $1 / 0868 / 11$. The authors are thankful to the participants of the Course of Polar Ecology organised by the University of South Bohemia in Česke Budějovice in Svalbard in July 2011 for their help during sampling in the field. S.K. Das kindly improved our English. 
Despite a long history of interest in terrestrial algae in polar environments, several aspects are rather unexplored and require further investigation. Very little is known about algal flora associated with bone remnants analogous as we know on stone substrate. The bone remnants frequently dispersed everywhere in coastal areas of polar region represent a specific natural habitat which is colonized by microscopic algae. However, these habitats are not included in ecological studies. The bones are specific anthropogenic substrate providing a niche for organisms in extreme conditions. The stable environment inside the bone is suitable for the growth of numerous organisms. Algae

\section{Material and Methods}

The samples were collected from the central part of Svalbard Archipelago in Petuniabukta in July 2011 from the mammalian bone remnants of whales, seals and reindeers, strewed in deglaciated coastal areas covered by tundra vegetation $\left(78^{\circ}\right.$ $\left.40^{\prime}-78^{\circ} 44.5^{\prime} \mathrm{N}, 16^{\circ} 26^{\prime}-16^{\circ} 40^{\prime} \mathrm{E}\right)$. The small fragments of dry bone remnants were transported to a laboratory in sterile plastic bags and unialgal strains were isolated from them following traditional culture methods. Cultures of the strains used in this study were maintained either in liquid or agarized Zehnder medium at $15^{\circ} \mathrm{C}$ under a $16 / 8 \mathrm{hr}$ light/dark cycle with a photon flux density of $50 \mu \mathrm{mol} \mathrm{m} \mathrm{m}^{-2}$ of photosynthetically active radiation pro- grow in microspaces in bone tissue which helps them to avoid the stress like cold temperature, fluctuations in irradiance and freezing. In the bones a lot of biogenic elements such as e.g. calcium and phosphorus (Reeb et al. 2011) is available. Therefore, bone remnants are very interesting substrata for growth of cyanobacteria and algae. However, relevant data from polar regions are almost absent.

The present study reports four newly recorded algal species grown on skeletal remnants of mammals (whales, seals and reindeers), collected during June 2011 in the Petuniabukta, Billefjorden, the central part of Svalbard Archipelago.

vided by a daylight fluorescent lamps. The phenotypic characteristics were studied in regular time intervals at different growth phases of the algae. Linear drawings and photomicrographs were made using a Leica DM 2500 (Germany) light microscope with Nomarski contrast, fitted with a Leica DFC 290 HD camera and operated by LAS 3.5.0 software. Suitable Monograph (Ettl et Gartner, 1995) and research papers (e. g. Broady 1979, Matuła et al. 2007) were followed for identification of algal strains. All the strains were deposited at the Working Culture Collection of Algae at Department of Botany, Comenius University in Bratislava, Slovak Republic.

\section{Results}

A total of 14 taxa of cyanobacteria and algae were identified on mammalian bone remnants of which genera Chlorella, Stichococcus and Phormidium were abundantly present in almost each sample. The following 4 species: the green algae Pseudodyctiochloris multinucleata and Tetracystis pulchra, the stramenopile algae Xanthonema debile and Heterococcus papillosus represent new records from the Svalbard Archipelago. Therefore, they are characterized in more details in the following text. 

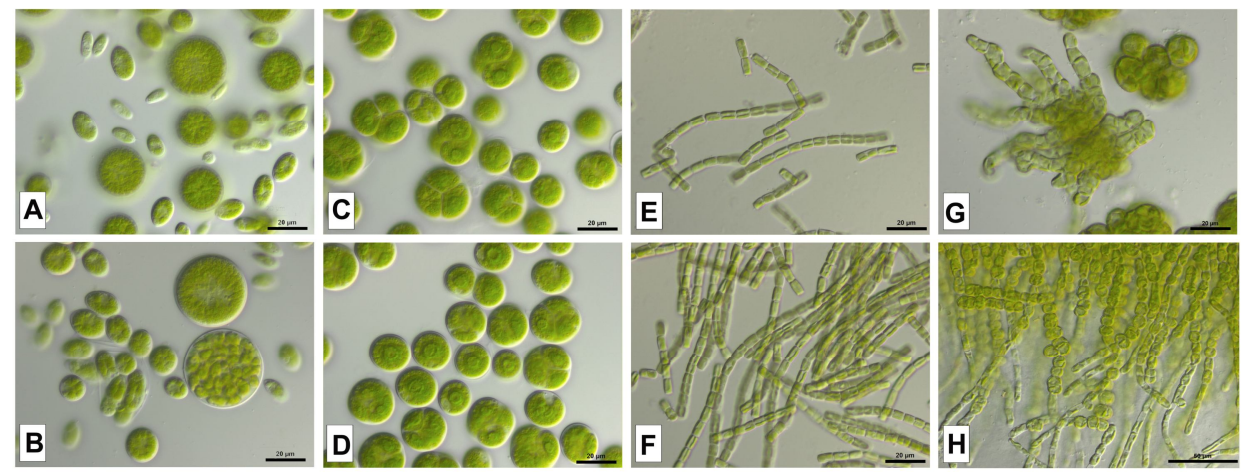

Fig. 1. Photomicrographs of: A, B - Pseudodyctiochloris multinucleata, C, D - Tetracystis pulchra, E, F - Xanthonema debile, G, $\mathbf{H}-$ Heterococcus papillosus. Scales for figures $\mathbf{A}-\mathbf{F}$ represent $20 \mu \mathrm{m}$, for figures $\mathbf{G}$ and $\mathbf{H}$ represent $50 \mu \mathrm{m}$.

Pseudodyctiochloris multinucleata (Broady) Ettl et Gärtner 1987; (Figs 1A, B; 2A )

Syn.: Signiosphaera multinucleata Broady 1977

Cells solitary with thick cell-wall, oval or like lemon form, (9) $11-14$ (15) $\mu \mathrm{m}$ in diameter and pale green in colour. Chromatophore solitary, centrally placed without pyrenoid. Cells are multinucleate. Reproduction by motile zoospores with two equal flagella and red stigma. Sporangium (18) $28-60$ (64) $\mu \mathrm{m}$ in diameter.

Tetracystis pulchra Brown et Bold 1964; (Figs 1C, D; 2B)

Cells solitary or packed in tetraedric group, sometimes clustered to form big complex. Cells oval or irregular, (9)10 - 12 (15) $\mu \mathrm{m}$ in diameter. Cell wall thin, not gelatinous. Cells arranged densely in well visible colourless mucilage. Chromatophore solitary with one central pyrenoid. Dark green in colour, orange in older ones. Reproduction is by colony desintegration.

Xanthonema debile (Vischer) Silva 1979; (Figs 1E, F; 2C)

Syn.: Heterothrix debilis Vischer 1936

Solitary, no branching, smaller filaments, dark green colour trichomes. Cells long or barrel shaped with 2 or more chromatophores without pyrenoid. Cells $4-5 \mu \mathrm{m}$ wide and (5) 6 - 10 (11) $\mu \mathrm{m}$ long. Reproduction by motile zoospores with two equal flagella, 1or 2 chromatophores and red stigma.

Heterococcus papillosus Pitschmann 1963; (Figs 1G, H; 2D)

Cells solitary or packed in group, $12-15 \mu \mathrm{m}$ in diameter. Colour is pale green , in oldest phase dark green. In warmer conditions have a growth like, ,rootlet" in space.Cells with numerous chromatophores without pyrenoid. Colony is desintegrated in three levels. Reproduction by motile zoospores with two unequal flagella, 1 or 2 chromatophores and red stigma. 

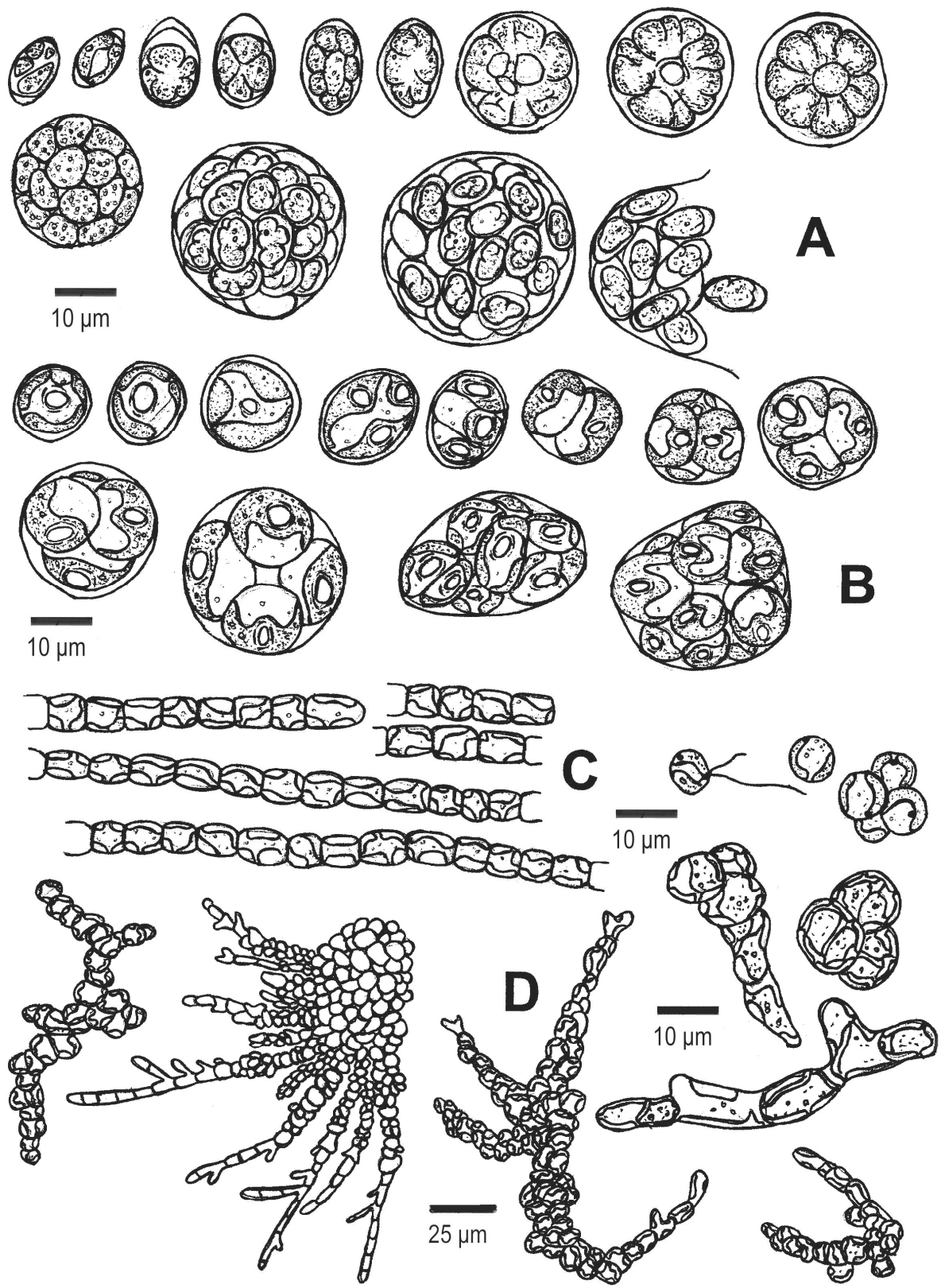

Fig. 2. Linear drawings of: A - Pseudodyctiochloris multinucleata, B - Tetracystis pulchra, C-Xanthonema debile, D - Heterococcus papillosus. 


\section{Discussion}

The first floristic remarks about the living microorganisms associated with bone remnants are from Reeb et al. (2011). The authors report the finding of bacteria, Ascomycota fungi and Stichococcus-like trebouxiophyte green algae which inhabited the cavities of bone remnants from a bison carcass in Yellowstone National Park. In general, these microbes appear to be opportunists that have colonized an isolated oases that provided nutrients and protection from desiccation and UV radiation. In addition, the bone remnants are ecologicaly important anthropogenic substrata with hight impact to cycle of nutrients in nature. No doubt that this special substrate quite common in polar environment could be also a refuge for inhabitance of interesting algal taxa as documented in this study from Svalbard.

Green algae (s.l.) are the dominant group of algae in Svalbard tundra as reported in earlier published records (Oleksowicz et Luścińska 1992, Skulberg 1996, Kaštovská et al. 2005, Kim et al. 2008, 2011, Matuła et al. 2007, Richter et al. 2009). In addition to recent knowledge, we presented four algal species associated with the mammalian skeletal remnants in this study. Pseudodyctiochloris multinucleata, Tetracystis pulchra, Xanthonema debile and Heterococcus papillosus are significant contribution to Svalbard algal flora recorded for the first time.

According to previous studies from this region Leya et al. (2000), Tetracystis on the genus level in their list of cryophilic and soil algae persited on snow fields in Northwest Spitsbergen. Similarly, Stibal et al. (2006) mentioned Heterococcus on the genus level only in their list of algae from supraglacial sediment samples from glaciers in the vicinity of the Baranowski field station. The stramenopile alga determined as Xanthonema cf. sessile is reported by Stibal et al. (2006) from the same environment also. However, the descriptions or ilustrations to these taxa are absent the above in mentioned papers.

Further study of mammalian bone remnants from polar regions could bring not only discovery of the new algal taxa, but also the new information on their ecophysiological properties. This would help to understand better the life strategy of algal species, and other microbiota in conditions of extreme environment.

\section{References}

Broady, P. A. (1979): The terrestrial algae of Signy Island, South Orkney Islands. British Antarctic Survey, Scientific Reports, 98: 1-117.

ELSTER, J., BENSON, E. (2004): Life in the polar terrestrial environment with a focus on algae and cyanobacteria. In: B. Fuller, N. Lane, E. Benson (eds.): Life in the Frozen State. Boca Radon, London, New York, Washington, D.C., CRC Press, p. 111-150.

EtTL, H., GÄrTnER, G. (1995): Syllabus der Boden-, Luft- und Flechtenalgen. Gustav Fischer Verlag, Stuttgart, Jena, New York, 1995, 729 p.

KaŠTOVSKÁ, K., ElSTer, J., Stibal, M. and ŠAnTRŮČKOVÁ, H. (2005): Microbial assemblages in soil microbial succession after glacial retreat in Svalbard (High Arctic). Microbial Ecology, 50: 396-407.

Kim, G. H, KLOchKova, T. A. and Kang S. H. (2008): Notes on freshwater and terrestrial algae from Ny-Álesund, Svalbard (high Arctic sea area). Journal of Environmental Biology, 29: 485491. 
Kim, G. H., Klochkova, T. A., Han, W. J., Kang, S.-H., Choi, G. H., Chung, K. W. and Kim, S. J. (2011): Freshwater and terrestrial algae from Ny-Ålesund and Blomstrandhalvøya Island (Svalbard). Arctic, 64: 25-31.

LeyA, T., Müller, T., LiNG, H. U. and Fuhr, G. (2000): Taxonomy and biophysical properties of cryophilic microalgae and their environmental factors in Northwest Spitsbergen, Svalbard. $57^{\text {th }}$ Eastern Snow Conference, Syracuse/NY, USA, 7 p.

Matula, J., Pietryka, M., Richter, D. and Wojtuń, B. (2007): Cyanoprokaryota and algae of Arctic terrestrial ecosystems in the Horsund area, Spitsbergen. Polish Polar Research, 28: 283315 .

OlekSOWICZ, A. S., LuŚCiŃSKA, M. (1992): Occurrence of algae on tundra soils in Oscar II Land, Spitsbergen. Polish Polar Research, 13: 131-147.

Reeb, V., Kolel, A., McDermott, T. and Bhattacharya, D. (2011): Good to the bone: microbial community thrives within bone cavities of a bison carcass at Yellowstone National Park. Environmental Microbiology, 13: 2403-2415.

Richter, D., MAtuŁa, J. and PietryKa, M. (2009): Cyanoprokaryota and algae of selected tundra habitats in the Horsund fjord area (West Spitsbergen). Oceanological and Hydrobiological Studies, 38: 65-70.

Skulberg, O. M. (1996): Terrestrial and limnic algae and cyanbacteria. Part 9. In: A. Elvebakk, P. Prestrud (eds.): A catalogue of Svalbard plants, fungi, algae and cyanobacteria. Norsk Polarinstitutt Skrifter, 198: 383-395.

STIBAL, M., ŠABACKÁ, M. and KAŠTOVSKÁ, K. (2006): Microbial communities on glacier surfaces in Svalbard: impact of physical and chemical properties on abundance and structure of cyanobacteria and algae. Microbial Ecology, 52: 644-654.

Thomas, D. N., Fogg, G. E., Convey, P., Fritsen, C. H., Gili, J. M., Gradinger, R., LaybournParry, J., Reid, K. and Walton, D. W. H. (2008): The Biology of Polar Regions. Oxford University Press, Oxford, 2008, 394 p. 